\title{
Lysionotus chatungii - a new species of Gesneriaceae from Arunachal Pradesh in North-Eastern India
}

\author{
Momang Taram, A. P. Das and Hui Tag' \\ Plant Systematic and Ethnobotanical Research Laboratory, Department of Botany, Rajiv Gandhi \\ University, Rono Hills, Doimukh-791112, Arunachal Pradesh, India \\ ${ }^{1}$ Communicating author; E-mail: huitag2008rgu@gmail.com
}

[Received 01.12.2019; Revised ..12.2019; Accepted ..12.2019; Published 31.12.2019]

\begin{abstract}
Lysionotus chatungii M.Taram, A.P Das \& H.Tag, a new species of Gesneriaceae is described from Geku in Upper Siang District of Arunachal Pradesh in North-Eastern India. The new species is presented here along with its detailed description, habitat structure and distribution along with a plate of color photographs for its easy recognition.
\end{abstract}

Key words: Gesneriaceae, Lysionotus chatungii, New species, Arunachal Pradesh.

\section{INTRODUCTION}

The genus Lysionotus D.Don (1822) is distributed from North India and Nepal eastwards through South China, Taiwan, Bhutan, Laos, Myanmar, North Thailand, North Vietnam to South Japan (Moller et al. 2017). According to Moller et al. (2017) 6 species of Lysionotus are found in India and 3 species of Lysionotus in North East India (Sinha \& Dutta 2016). Giri et al. (2008) recorded 3 species (L. atropurpurea H.Hara, L. palinensis G.D. Pal and L. serratus D.Don). Recently two new taxa of Lysionotus viz. L. gamosepalous W.T Wang var. biflorus A.Joe et al. (2017) and L. bijantiae D.Borah \& A.Joe (2018) have been described from Arunachal Pradesh. In this article another new species of Lysionotus is presented from Arunachal Pradesh in North Eastern India. The new species is described here and illustrated with a plate of color photographs. With this new species described herein, there are now five species and two varieties of Lysionotus recorded from Arunachal Pradesh as well as from Northeastern India.

\section{Taxonomy}

Lysionotus chatungii M.Taram, A.P. Das \& H.Tag, sp.nov. [PLATE - I]

Lysionotus chatungii is morphologically similar to Lysionotus chingii Chun ex W.T. Wang but can be easily distinguished by a number of characters like lamina sub-coreacious lamina (vs. papery/chartaceous); ovate-elliptic to rounded-ovate (vs. elliptic-oblong); base obliquelycordate to rounded (vs. cuneate); calyx divided from base (vs. calyx divided up to the middle) (Table 1)

Type: INDIA, Arunachal Pradesh: Upper Siang District, Geku. $28^{\circ} 272483 \mathrm{~N}$ and $95^{\circ} 82$ 103 E; Elevation 873 m; 15 April 2019, Momang Taram 0301 [Holotype CAL; Isotypes ASSAM, ARUN] 


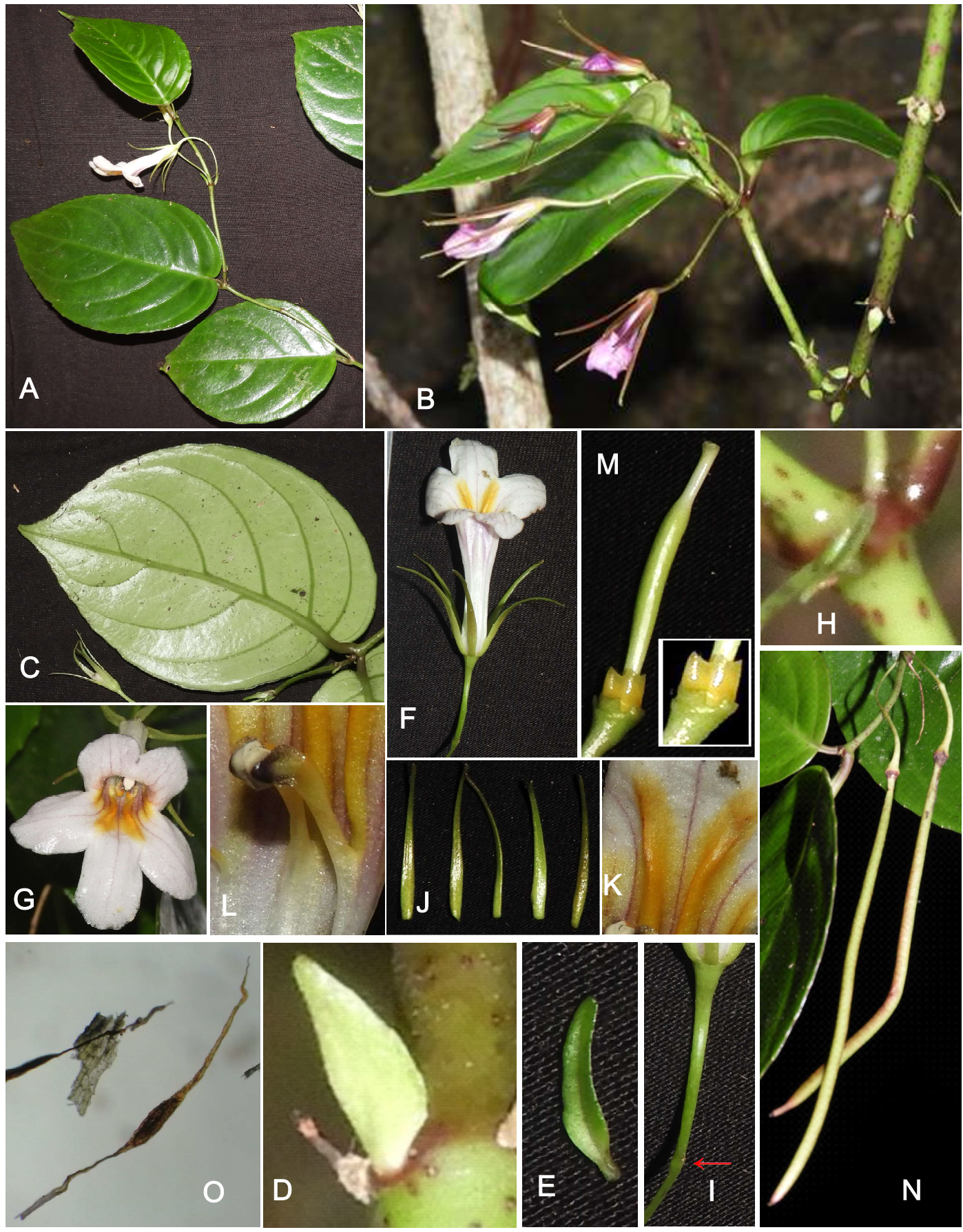

PLATE - I. Lysionotus chatungii M.Taram, A.P. Das \& H.Tag: A. Twig with alternate leaves; B. Twig with opposite leaves and 4-nate in prophyll bearing portion; C. Lamina with unequal and slightly cordate base; D \& E. Prophylls; F. Flower in lateral view; G. Flower in front view; H. Emergence of peduncle from axiles of petiole and prophyl; I. Union of peduncle and pedicel with articulation showed by arrow (bract absent); J. Sepal lobes; K. Corolla throat inside with two calli; L. Two stamens with adherant anthers; M. Pistil with disc; N. Mature follicles; $\mathbf{O}$. Seed. 
Epiphytic, or on rocky-walls, root-climbing or creeping sub-shrub, $150-300 \mathrm{~cm}$ long, terete, much branched, glabrous, young stem green with purple irregular blotches, mature stem brown; internodes $2-12 \mathrm{~cm}$. Leaves mostly opposite, but may be alternate, even ternate or in whorl of 4; sometimes two leaves of normal shape and size are alternating with prophylls; 4 or more prophylls occur at every node in lower non-leafy part of branches; Petioles $0.5-1 \mathrm{~cm}$, glabrous, purple; Lamina ovate-elliptic to rounded ovate, $7-20 \times 5-12 \mathrm{~cm}$, nearly entire to minutely dentate to obscurely serrate, shortly caudate-acuminate, base rounded to shallowly cordate, generally oblique, lateral veins sub-opposite $4-8$ on each side of midrib, adaxially dark green, abaxially whitish green with purple blotches, glabrous, sub-coreaceous. Inflorescence axillary, $2-4$ in each node, 1-flowered (cymose-solitary) each; peduncle slender, $3.0-4.0 \mathrm{~cm}$ long, terete, green with purple irregular blotches, glabrous, attachment with pedicel prominently articulated; pedicel slender but slightly thicker, $2.0-2.5 \mathrm{~cm}$ long, terete, purple, glabrous. Peduncles not arising from leaf-axile are with a ovate to oblong prophyll $(0.4-1.0 \mathrm{~cm} \times 0.1-$ $0.3 \mathrm{~cm}$ ) at base. Calyx divided into 5 lobes from base; each lobe slender-linear to linearsubulate, anterior 3 longer [ $1-2 \mathrm{~cm}$ x $0.1-0.2 \mathrm{~cm}]$, posterior 2 shorter $[0.7-1.3 \mathrm{~cm} \times 0.1-0.2$ $\mathrm{cm}]$, or sometimes all equal, entire, narrowly acuminate, glabrous, purple. Corolla bilabiate, $3+$ 2, anterior lip deeply 3-lobed, $0.6-1.2 \mathrm{~cm}$ long, sub-equal, ovate, more or less entire, rounded; posterior lip obscurely 2-lobed, $0.4-0.8 \mathrm{~cm}$ long, glabrous, white-purplish with deep-purple reticulation, tube $1.6-2.3 \mathrm{~cm}$ long, slightly inflated upwards, $4-4.3 \mathrm{~cm}$ long, glabrous, purplish with deep-purple stripes and 2 yellow elongated calli at throat alternating with anterior lobes. Stamens 2, included, filaments $0.5-0.7 \mathrm{~cm}$ long, attached to corolla tube along the two margins of the anterior lip, terete, yellow, glabrous, curved and blackish at the tip, connected to the middle of anther; anthers broadly oblong (oblate), cohering each-other face-to-face, white,

Table 1. Comparison of Lysionotus atropurpureus and Lysionotus chingii with the new species Lysionotus chatungii

\begin{tabular}{|c|c|c|c|}
\hline Characters & $\begin{array}{l}\text { Lysionotus atropurpureus } \\
\text { Hara }\end{array}$ & $\begin{array}{l}\text { Lysionotus chingii Chun } \\
\text { ex W.T. Wang }\end{array}$ & Lysionotus chatungii sp. nov. \\
\hline Habit & Epiphyte & Climbing sub-shrubs & Climbing sub-shrubs \\
\hline Stem length & Up to $25 \mathrm{~cm}$ & $\mathrm{Up}$ to $9 \mathrm{~m}$ & $\mathrm{Up}$ to $3 \mathrm{~m}$ \\
\hline Petiole & $0.5-1.5 \mathrm{~cm}$ & Longer, up to $2.3 \mathrm{~cm}$ & $\mathrm{Up}$ to $1.0 \mathrm{~cm}$ \\
\hline $\begin{array}{l}\text { Lamina } \\
\text { shape }\end{array}$ & $\begin{array}{l}\text { Oblong lanceolate to } \\
\text { narrowly elliptic }\end{array}$ & Elliptic to oblong & $\begin{array}{l}\text { Ovate-elliptic to rounded- } \\
\text { ovate }\end{array}$ \\
\hline texture & Papery & Papery & Sub-coriaceous \\
\hline margin & Denticulate & $\begin{array}{l}\text { Entire to denticulate with } \\
\text { small glands }\end{array}$ & $\begin{array}{l}\text { Entire to minutely dentate to } \\
\text { sub-serrate without glands }\end{array}$ \\
\hline base & Cuneate & Broadly cuneate to cuneate & $\begin{array}{l}\text { Rounded to obliquely and } \\
\text { shallowly cordate }\end{array}$ \\
\hline apex & Acuminate & Acuminate & Shortly caudate-acuminate \\
\hline Inflorescence & Cymes $1-4$ flowered & Solitary & Solitary \\
\hline Bracts & Linear & Orbicular- ovate & Ebracteate \\
\hline Peduncle & $5.5-7.5 \mathrm{~cm}$ & $1.4-2.8 \mathrm{~cm}$ & $2.7-4.0 \mathrm{~cm}$ \\
\hline Pedicel & $0.7-2 \mathrm{~cm}$ & $0.2-0.7 \mathrm{~cm}$ & $1.4-2.5 \mathrm{~cm}$ \\
\hline Calyx & Divided from base & $\begin{array}{l}\text { Divided above middle; } \\
\text { lobes equal; tube } 1.2-1.8 \\
\mathrm{~cm}\end{array}$ & $\begin{array}{l}\text { Divided from base; posterior } 2 \\
\text { lobes shorter; tube absent }\end{array}$ \\
\hline Corolla & Purple & $\begin{array}{l}\text { Tinged greenish; } 3.3 \mathrm{~cm} \\
\text { long }\end{array}$ & $\begin{array}{l}\text { White-purplish with deep- } \\
\text { purple reticulation; tube } 1.6- \\
2.3 \mathrm{~cm} \text { long }\end{array}$ \\
\hline Disc & Ring-like with entire margin & $\begin{array}{l}\text { Ring-like with entire } \\
\text { margin }\end{array}$ & $\begin{array}{l}\text { 4-lobed, lobes oblong with } \\
\text { conical tips }\end{array}$ \\
\hline $\begin{array}{l}\text { Flowers \& } \\
\text { fruits }\end{array}$ & July - October & July - September & March - August \\
\hline
\end{tabular}


dehiscing longitudinally, unappendaged; staminodes $2,0.1-0.3 \mathrm{~cm}$ long, linear, yellow. Ovary $2 \mathrm{~cm}$ long, shortly stipitate, cylindrical, greenish, glabrous; style $0.5 \mathrm{~cm}$ long, terete, glabrous; stigma slightly bilamillate. Nectary 4-lobed, lobes erect, oblong with conical tip. Capsules $10-$ $12 \mathrm{~cm}$ long, linear, glabrous, dehiscing longitudinally; Seeds $0.3-0.4 \mathrm{~cm}$ long, linear, with along slender funiculus at base and long brownish hair-like appendage at the tip.

Affinities: The habit and solitary inflorescence of new species Lysionotus chatungiiis similar with Lysionotus chingii. However, the new specie is distinguished from it by much shorter stem length; sub-coriaceous leaves; ovate-elliptic to rounded-ovate lamina withrounded to obliquely-cordatebase; calyx segments divided to the base.

Another somewhat similar looking species, Lysionotus atropurreus Hara is also available in North-east India including Arunachal Pradesh (Giri et al. 2008). However, structurally/ morphologically it is a completely different plant as in numerous important characters like habit, leaf structure, inflorescence, flower structure etc. the new species is completely unique.

Table 1 shows the differences of the new species, Lysionotus chatungii with that of L. chingii and L. atropurpureus.

Flowering and Fruiting: Flowering start from March and fruiting ends in August.

Etymology: This species is named after Late Taro Chatung, the first and the most famous journalist of Arunachal Pradesh whose contribution in journalism for this remote state is immense.

Distribution, Threat-status and Ecology: So far, the new species known only from its Type-locality in the Upper Siang district of Arunachal Pradesh in Northeastrn India and can be treated as endemic. The plant was found growing on rocks and on tree-trunks in moist shaded areas along the margin of a narrow but perennial stream. The estimated area of its occurrence is less than $3 \mathrm{~km}^{2}$ and the population is thought to be less than 100 individual. It was growing in association with Mosses, Asplenium sp., some epiphytic ferns, Aeschynanthus parviflorus (D.Don) Spreng., Codonanthe devosiana Lem., etc.

\section{Acknowledgements}

The authors are thankful to Dr. Sudeshna Datta of Botanical Survey of India for her useful comments on the specimen and to Mr. DIpankar Borah for his help in the laboratory. They are also thankful to Mr. Ojar Taku, Mr. Bosong Taram, Olom Tosung and Mr. Gemin Taku for their logistic supports during the field works.

\section{LITERATURE CITED}

Borah, D. \& Joe, A.2018. A new species of Lysionotus (Gesneriaceae) from Northeastern India. Taiwania 63(3): $232-234$.

Don, D. 1822. Description of two new genus of Nepal plants. Edinburgh Phil. J. 7: 82 -86.

Giri, G.S.; Pramanik, A. \& Chowdhery, H.J. 2008. Materials for the Flora of Arunachal Pradesh. Vol. II. Botanical Survey of India, Kolkata.

Joe, A.; Hareesh, V.S. \& Sabu, M. 2017. A new taxon of Lysionotus (Gesneriaceae) from Northeastern India. Taiwania 62(4): 337 - 339.

Moller, M.; Nampy, S.; Janeesha, A.P. \& Weber, A. 2017. The Gesneriaceae of India: Consequences of updated generic concepts and new family classification. Rheedea 27(1): $23-41$.

Sinha, B.K. \& Datta, S. 2016. Taxonomic account on the family Gesneriaceae in Northeast India. Nelumbo 58: 1 - 43 